\title{
Analysis the Changes Opinion on Qualified be Disclaimer Opinion to the Financial Statements Local Government (Case Study: Government of Palopo city)
}

\author{
A. Dahri Adi Patra, Lanteng Bustami \\ STIE Muhammadiyah Palopo, Indonesia \\ andidahri1959@yahoo.com
}

\begin{abstract}
The purpose of the research was to analyze, why the changes Opinion report of examination by the Supreme Audit Board on Qualified Opinion be Disclaimer opinion to the Financial Statements of the Local Government Palopo city, fiscal year 2013 , using a qualitative analysis approach to interactive model (collection of data - reduction data -display and conclusion Verifying ). In the phase Display of data, through analysis of Patterns of relationship between the findings of the report examination and interviews with stakeholders, obtained, information that the Competence of Human Resources (HR) and the Internal Control System has a strong interactive relationship and the direction. In analysis conclusion and verification showed that aspects of human resources (HR) is the most influential of the changes Opinion report examination Supreme Audit Board, is an aspect of behavior (Ethics). Thus the conclusion of the study; Behavior (ethics) dishonest is a major factor Changes opinion report Supreme Audit Board of Qualified opinion be Disclaimer opinion As the application of this research in the future, it is recommended to formulation of the action plan to the Unqualified Opinion. Through Team Supervise and monitoring implementation of action plan for improvement of Internal Control System and completion finding Auditor, as well improving the competence of personal financial management, on education through training administration and Regional Financial Accounting.
\end{abstract}

Keywords: Internal Control System, Leadership Commitment, Competence Human Resources and Opinion the supreme Audit Board

\section{Introduction}

Reform the system of Regional Finance Administration in terms of budgeting, administration and financial accountability is basically a change of Government Accounting System of Single Entry systems General Cash Book to Double Entry with Financial Accounting System Area beginning with the enactment of a package of Law (Act) which consists of; Law (Act) No. 17 of 2003, concerning State Financial Management; Law (Act) No. 1 of 2004, on State Treasury and Law (Act) No. 15 of 2004, regarding the Audit, Management and State Financial Responsibility. The third Pilosofi Act is to give a mandate to the organizers Government as a shareholder mandate from the people to manage state and local finances in a transparent and accountable through the administration and financial reporting process according Indonesian Governmental Accounting Standards. Clause 31, paragraph 1, of Law number 17 of 2003, states that the Governor / Regent / Mayor, presented the draft Regulation questioned the Implementation of the budget to Parliament in the form of financial statements which have been audited by the Supreme Audit board not later than 6 (six) months after the fiscal year ends.

In clause 56 paragraph 4, of Law No. 1 of 2004 states that; heads of regional organizations as budget users / users of goods provide a statement that the management of the budget in the workplace has been organized by the Internal Control System that adequate and appropriate financial statements have been organized Government Accounting Standards. Opinion Report of Examination of Supreme Audit board to 524 local government financial reports in 2012 and 2013: in 2012, unqualified 23\%, Qualified 61\%, Adverse 15\% and Disclaimer 1\%. For the year 2013, unqualified 30\%, Qualified 59\%, Adverse 9\% and Disclaimer $2 \%$. (Overview Opinion Report of Examination of Supreme Audit board -II 2014) of the overview report of Supreme Audit board seen significant increase in the number of Local Government Finance Report who obtained the Opinion unqualified and Qualified; in 2012, 84\% who obtained Opinion unqualified and Qualified, in 2013 rose to $89 \%$ and are still problematic (Adverse and Disclaimer) decreased from 16\% to 
$11 \%$. The interesting thing authors to conduct research on the amendment Opinion of Qualified became Disclaimer case study of the Palopo city, that nationally the quality of Local Government Finance Report, the better, as shown in an overview report of Supreme Audit board number local government financial reports year 2013 to obtain unqualified and Qualified, amounted to 89\%, an increase of 5\% compared to 2012 . On the other the Government of Palopo city experienced a "decreased" of Opinion qualified Opinion be Disclaimer Opinion.

\section{Literature Review}

Study, entitled, Effects of Internal Control System on the Quality of Financial Statements, with the conclusion that the Internal Control System and significant positive affect on the quality of the financial statements $83 \%$ (Herawati, 2014). Research Susilawati and Riana (2014), Government Accounting Standards and Internal Control System as Antecedents Quality Financial Statements, with the conclusion of the Government Accounting Standards and the Internal Control System simultaneously have a significant impact on the financial statements of Local Government 52\%, Internal Control System gives positive and significant impact on the quality of government financial reports 74\%. Research analysis of Arfianti \& Kawedar (2011) on factors affecting the value of the local government financial reporting information concluded that the internal control system is positive and significant impact on the financial reporting of local government. Three researchers above using quantitative analysis and show the results of how strong the relationship of influence and a significant degree of Internal Control System on the quality of financial statements between $74-83 \%$, it is in line with the findings of Supreme Audit board that Local Government Finance Report disclaimer or unnatural generally caused by Internal Control System weakness. To this the researcher uses qualitative analysis to examine the factors that influence changes in Supreme Audit board opinion of Qualified became Disclaimer.

Government Internal Control System: Government Internal Control System in Government Regulation No. 60 of 2008, based on the idea that the internal control system attached to all the activities and influenced by human resources and only provides reasonable assurance is not an absolute. Based on these thoughts, developed elements of the Internal Control System, which serves as the Implementation Guidelines and Benchmark Testing Effectiveness Internal Control System implementation by considering the costs and benefits (Cost and Benefit). Background issuance of Government Regulation No. 60 of 2008, concerning the Government Internal Control System is as the guidelines of the State Finance Reform Package to the Good Governance and Good Government. The elements present in Government Internal Control System refers to the elements of the internal control system that has been practiced in the government in various countries which include; a). Control environment. b). Risk Assessment, c), Control Activities, d). Information and communication, e). Monitoring of internal control. According to (Moeller, 2007), Internal Model control Coso version, described as a Rubic Cube, where the application of the five mutually reinforcing elements tailored to the shape of the organization to compliance reporting financial operations through effective and efficient activities, reliability of financial reporting, asset security and compliance regulations. This means weakness Internal Control System affects the quality of the reliability of financial reporting, asset security and non mainstay; the financial statements affect the internal control system, which in turn affects the Audit board Opinion on the financial statements of local governments.

Definition and Type Opinion: Opinion is the statement of professional inspectors on the fairness of the financial information presented in the financial statements that are based on the criteria of (i) compliance with government accounting standards, (ii) the adequacy of disclosures (adequate disclosures), (iii) compliance with laws and regulations, and (iv) the effectiveness of internal control systems. (Act No. 15 of 2004, section I of article 1 point 1). Under the law number 15 of 2004, there were four (4) types of opinions given by the Supreme Audit Board on the examination of local government financial statements (Suwanda, 2013).

a. Unqualified opinion. This opinion was given because the examiner believes, based on the results of the examination of evidence collected, the financial statements are free of the errors or mistakes that material, namely; (i) Presentation of financial statements conducted in accordance Government Accounting System, there are no material misstatements and adequately disclosed, (ii) internal control system constructed / set have been quite adequate. So as to secure the property and management 
policies, (iii) all transactions are conducted in accordance applicable provisions (no material findings that influence the opinion of the examination results.

b. Qualified Opinion. Opinion given because although there are mistakes, but the mistakes and errors do not affect the overall fairness of the financial statements, namely; (i) the presentation of the financial statements has been conducted in accordance Government Accounting Standards, (ii) Internal Control System that have been constructed / set will be sufficient, (iii) all transactions are conducted in compliance regulations, except for the material to be excluded, the examiner did not gain confidence adequate.

c. Adverse Opinion. Opinion given because the examiner believes based on the evidence collected, that the financial statements of the audited entity contain a lot of mistakes or errors that material. It means that the financial statements do not portray the financial condition correctly.

d. Disclaimer Opinion. Can not mean that the financial statements are true or false, opinions given since the examiner cannot believe whether the financial statements are true or false. his happens because the examiner is not able to obtain the evidence needed to conclude and declare whether the financial statements have been presented correctly or incorrectly, ie; (i) are very material financial statement presentation by the local government, do not conform with the Government Accounting Standards (SAP) and many transactions and assets cannot be traced; or (ii) SPI constructed / set inadequate, so it can not secure the property and management policies, or (iii) transactions made many deviations are very material, or (iv) the scope of the Supreme Audit board, constrained by an object examination of that government area (Suwanda, 2013).

Qualitative Characteristics of Financial Statements: The qualitative characteristics of financial statements are normative measures that need to be realized in the accounting information so that it can fulfill its purpose. The following four characteristics is a prerequisite normative necessary in order to meet the government's financial statements desired quality. (Government Regulations N0. 71 of 2010)

a. Relevant: Financial statements can be said to be relevant if the information contained in it can affect the user's decision helps in evaluating the events of the past or the present and predict the future, and confirm or correct the results of their evaluations in the past. Accordingly, the financial statements of the relevant information can be linked to the intended use. Relevant information should have the benefit of feedback, predictive, timely and complete. (PP 71 in 2010).

b. Reliability: The information in the financial statements is free from errors and misleading understanding of material, presenting any facts in an honest and verifiable. Information may be relevant, but if the nature or presentation of unreliable then uses that information could potentially misleading. Meet the characteristics of reliable information; presentation honest, verifiable and mortalities.

c. Comparability: Information contained in the financial statements would be more useful if it can be compared with the previous year's financial statements or other reporting entity's financial statements in general.

d. Understandability: The information presented in the financial statements can be understood by the user and is expressed in the form and adapted to the understanding of the users. To that end users are assumed to have sufficient knowledge of the activities and operating environment reporting entity, as well as the willingness of users to learn the information in question.

\section{Methodology}

The method used in this Research is descriptive with qualitative approach, namely a thorough trouble shooting procedures using exposing data obtained from interviews, observations of literature and field observations, then analyzed and interpreted to provide conclusions (Moleong-Lexy, 2002). Data collected through in-depth interviews by the Head of Department of Revenue Finance and Asset Management Area City palopo, Chief Inspectorate, Head of Accounting Department of Revenue Finance and Asset Management, to obtain information regarding changes in opinion supreme Audit board on Local Government Finance Report, of Qualified became Disclaimer Opinion, and then do a document search Local Government Palopo city ,Financial Statements and review of examination results and a summary report on the results of Supreme Audit board in 2014. 
Data analysis: Data analysis in qualitative research done since before entering the field, for the field, and after completion in the field (Sugiyono, 2013). In this case Nasution (1988) states "The analysis has been started since formulated and explained the problem, before plunging into the field, and continue until the writing of the research results. To this writer has explained and formulate problems prior research that why the "decline Opinion" of Qualified became Disclaimer. Logically and normative local government that has gained Qualified is not difficult to get an Unqualified opinion that seeks to improve the things that cause and exceptions by the Auditor on previous Local Government Finance Report examination.

\section{Figure 1: Components In Data Analysis (Interactive model)}

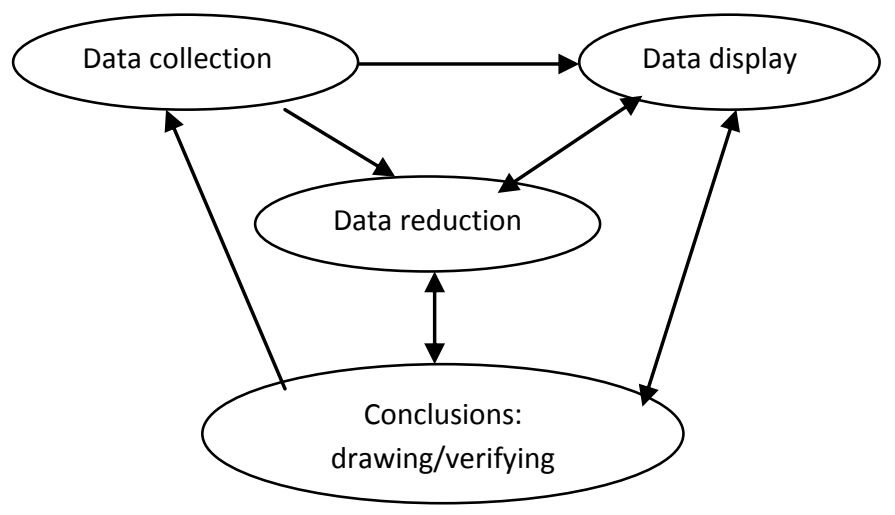

Data reduction: Data reduction means summarizing, choose things that are basic, focusing on things that are important, look for the theme of the pattern. Thus the reduced data will provide a clearer picture, and allows researchers to conduct further data collection.

Presentation of Data (Data Replay): In qualitative research, the presentation of data can be done in the form of brief descriptions, charts the relationship between categories flowchart and the like (Sugiyono, 2013; 91) is further recommended, in doing data display, in addition to the narrative text, also in the form of graphic, matrix and network. Against this study, researchers used a matrix, to see the pattern of the relationship between the data auditor of Supreme Audit board findings with data obtained through interviews with stakeholder financial management. The third step in the analysis of the qualitative analysis according to Miles and Huberman in Sugiyono; is the conclusion and verification. The conclusion of the study Qualitative may be able to answer the problem formulation formulated from the beginning (formulation while), but maybe not, and will be developed after researchers in the field.

Discussion: Changes Supreme Audit board opinion on Local Government Finance Report an entity of qualified opinion become disclaimer is an indication of just how weak financial performance of an entity in terms of (i) Effectiveness Internal Control System, (ii) adherence to legislation, (iii) the adequacy of disclosure, (iv) compliance with Standards government accounting. Additionally decrease the opinion also provides information that the Local Government Finance Report not completely with requirements of normative qualities desired in terms of relevant, reliable, comparable and understandable. From the document tracking Audit Reports by Supreme Audit board on Financial report of Palopo City Government in 2013, seen some things that are not believed by the auditor and deliver palopo city government gets a "decline Opinion" of qualified became Disclaimer, among others:

- There are differences in the value of the final balance on the account Cash Regions Bank Sulselbar of December 31, 2013 (in accordance with the confirmation of the results of the Bank) and presented in the Financial Statements of the Government Palopo city December 31, (unaudited) with a number of very material. Further investigation and clarification related officials, misuse of the local cash funds, cash funds disbursed through the area without using Warrant Disbursement or budget mechanisms. (Findings 1)

- There is a difference of medical supplies and medical devices ie the difference between the amount of inventories based on records storage / management with a countdown physical goods inventory that 
cannot be explained. Records and documents that are available do not allow Supreme audit Board to conduct adequate inspection procedures to believe in the value of the inventory. (Findings 2)

- Presentation of the value of non Permanent Investments - Revolving Fund is not supported by adequate documents and data. In addition Palopo City Government has not set accounting policy of grouping aging (aging Schedule), so that the balance of the revolving fund cannot be presented at their net realizable value. Records and documents that are available do not allow Supreme audit Board to conduct adequate inspection procedures to believe in the value of investments Non Permanent -fund rolling. (Finding 3)

- Fixed assets Balance at the beginning of the Balance Sheet as of December 31, 2013 differs from the balance based on data from the Regional Assets Division, in addition to the mutation Construction in Progress in 2012 the assets in 2013, cannot be traced. cards Goods Inventory and the book inventory at local work unit not reflect the actual value of fixed assets. (Findings 4)

- There are differences in the extent of Zone Other Asset-based partnerships with third-party cards Goods Inventory a with specified in the letter of agreement. (Findings 5)

- On presentation of short-term liabilities as of December 31,2013, the value of the debt is different hospitals with a recapitulation of invoices into debt supporting documents. (Findings 6)

- Total Expenditure Grant submitted to the Election Commission in accordance with the amount of evidence has not been questioned. To this audit board cannot trace because all the evidence is submitted to the State Attorney Palopo on $26^{\text {th }}$ November 2013, and have not returned until the examination ends. (Findings 7)

Furthermore, from the search results above findings, developed through interviews with the (1). Inspectorate as Government Internal Supervisory Apparaturs (2). Revenue Department business and Asset Finance as Regional Treasurer and (3). Accounting, as a unit which has the function of consolidating financial statements and preparing financial statements unit Local Government. From interviews, obtained information of the Chief Inspectorate that the findings of the above happens because; (i) weak Commitment and Integrity local work unit leadership in implementing the internal control supervision in local work unit, and for (ii). Apparatus competence internal examiner is still weak. (iii). Standard Operating Procedure that exist in each local work unit it is only a formality, have not been implemented optimally. Results of interviews, obtained information that the findings of the above happens because; (i) weakness in the Aspects of Regional Administration and Financial Reporting, (ii) Internal Control System that is not maximized in the implementation and some leaders still consider that SPI nature formalities, (iii). Officials / executive in charge of negligent and not careful in preparing the Financial Statements, (iv). Officials have not been optimal in carrying out its duties and responsibilities in accordance duties. (v). Authorized officials have yet to develop and establish a formal policy for one or all of the procedures, (vi). Less careful in planning and carrying out activities.

The results of interviews with Accounting obtained information that the competence of human resources in terms of finance and accounting administration of lacking both quantity and quality. Based on this information the data can be grouped the findings of the Supreme Audit Board on the financial statements palopo city government due to weaknesses in aspects;

- Implementation of Internal Control system of Government.

- Commitment and Integrity Leadership.

- Competence of Human Resources. 
Table 1: Matrix Pattern With The Relationship Between The Findings Supreme Audit Board with Internal Control system of Government Commitment Leader And Human Resources Competence

\begin{tabular}{|c|c|c|c|c|}
\hline No. & $\begin{array}{l}\text { Findings of } \\
\text { Audit Board }\end{array}$ & $\begin{array}{l}\text { Internal Control system of } \\
\text { Government }\end{array}$ & $\begin{array}{l}\text { Commitment } \\
\text { Leader }\end{array}$ & HR Competence \\
\hline 1 & Finding 1 & S (Strong) & S (Strong) & S (Strong) \\
\hline 2 & Finding 2 & S (Strong) & W (Weak) & S (Strong) \\
\hline 3 & Finding 3 & S (Strong) & S (Strong) & S (Strong) \\
\hline 4 & Finding 4 & V (Strong) & W (Weak) & S (Strong) \\
\hline 5 & Finding 5 & W (Weak) & S (Strong) & S (Strong) \\
\hline 6 & Finding 6 & S (Strong) & W (Weak) & S (Strong) \\
\hline 7 & Finding 7 & S (Strong) & W (Weak) & S (Strong) \\
\hline
\end{tabular}

To make it easier to analyze and understand what happened and led to a change of opinion became Disclaimer ( WDP), then the display of data in the form of relationship pattern between The findings of The Supreme Audit Board (BPK) with the results of interviews which information data; the implementation of the Internal Control System, Commitment and Integrity Leadership and Human Resource Competency with the symbol if there is a strong relationship marked (S) and if the relationship is weak given the symbol (W), as shown in the following matrix. From the matrix above shows that the most powerful aspects to do with the findings of the supreme audit board is the competence of Human Resources and Internal Control System, is also seen that the relationship between the competence of human resources and the Internal Control System is positive and direction, this means Aspects of Competence HR and Implementation Internal Control system of Government has a very strong relationship in influenced opinion Amendment supreme audit board. Thus based on the results of data reduction and data display after analyzed can be considered that the main cause of the "Decline" (changes) of qualified be Disclaimer opinion, is the weakness of human resource competencies and Internal Control System.

\section{Results}

The third step in the data analysis qualitative according to Miles and Huberman in Sugiyono is the conclusion and verification (Conclusions and verifying). Weaknesses in aspects of human resource competencies in the results above analyst data display is of a general nature cannot provide firm conclusions, in terms of what the competence of the Human Resources (HR) is considered weak financial management, it is necessary to further verification. In accordance with Government Regulation No. 101 of 2000, concerning education and training Position of Civil Servants, in Article 2, states that the Education and Training aims to improve the knowledge, skills and attitudes to be able to carry out the duties of office in a professional manner with based on personality and Ethics government employees.

Thus the competence of human resources (HR) State apparatus includes: (i) Knowledge, (ii). Skills and (iii) Ethics, for these investigators to obtain additional information that:

- Findings No. 1, the difference between the cash balance presented in the financial statements with the Local Government Regional Cash balances on bank accounts Sulselbar, is quite significant and potentially detrimental to the State/region, by the audit board assessed as engineering (false) to cover the cash transaction done without going through the budget mechanism. These findings associated with ethics, dishonest in reporting.

- Finding 2, the difference in supply of medicines and medical devices between the recording and the number of physical inventory count, this is the case because the board treasurer goods and the goods are not careful and do not discipline in conducting the inventory records as well as the direct supervisor is not routinely perform monitoring and checking the inventory, this happens because of 
lack of knowledge and also ethics managers do not discipline in administration and accounting records in accordance SAP.

- Findings number 3, on the balance of the revolving fund cannot be presented at net realizable value and not preparing accounting policy regarding aging (aging schedule), this happens because of lack of knowledge revolving fund managers as well as the lack of discipline (behavior) taking notes receivable revolving fund appropriate Government Accounting Standards

- Findings number 4 and number 5, the assets remain on the balance sheet at $31^{\text {st }}$ December 2013 is different from the balance of the assets based on the data field, as well as the extent of asset cooperation with third parties are not coextensive with those contained in the MOU, this happens because the recording and recognition of the value of assets, has not been fully supported by sufficient evidence of ownership and there are still assets controlled by the transferred officials, this means a lack of knowledge and discipline managers of regional assets and certain government officials who still control the assets.

- Findings number 6, the value of debt Hospital for unfinished construction work is different from the invoice recapitulation supporter; this happens because of lack of knowledge and discipline of financial administration officials to record debt Working Under Construction In Government Accounting Standards.

- Findings 7, the amount of grants that have not been submitted to the Election Commission in accordance with the amount of evidence of accountability, this happens because of lack of knowledge and discipline to manage the budget in accordance Government Accounting Standards

Based on data verification visible aspects of the resources of the most influential of the (seven) finding of audit board on Finance Report Government of Palopo is an element of ethics and Knowledge. The findings occur because of aspects of knowledge and expertise that is lacking, the impact of the findings is usually in the form of the findings of the administration, if the findings with dishonest behavior will directly impact the loss of the State / region as was the case in finding number 1. Behavior (ethics) dishonest if it is associated with the normative requirements, especially financial statements and the relevant criteria, the reliable finance report of Government Palopo city in 2013, has not been free of the notion that "misleading" and errors. Thus the researchers conclude that; behavior (ethics) dishonest in presenting the Local Government Finance Report is a Major Factor which led the regional government gets Assessment OPINION DISCLAIMER from the Supreme Audit Agency or in other words, even if the K knowledge and Skill nice but Conduct (ethics) apparatus unfavorable then the potential gain Disclaimer remain primarily the relevant criteria and reliability report Palopo City Government Finance in 2013, has not been free of the notion that "misleading" and material errors or otherwise does not meet the qualitative characteristics of financial statements.

\section{Conclusion and Recommendations}

Based on research studies on changes Supreme Audit Board Opinion of Qualified Opinion to Disclaimer Opinion approach Interactive data analysis model, summarized as follows:

- Changes in the Supreme Audit Board Opinion of Qualified to Disclaimer Financial Statements Palopo City Government in 2013, caused by deficiencies; on aspects of the Internal Control System, Leadership Commitment and Competence of Human Resources. (analysis Data Reduction)

- In the Display data analysis stage, the result that the most influential aspects of the changes Opinion Supreme Audit Board, is Kompetnsi aspects of human resources (HR) and the Internal Control System.

- Aspects of Human Resources and Internal Control System has a unidirectional relationship and very powerful in influencing change Supreme Audit Board opinion.

- In the analysis phase and Verification conclusion (Conclusion Drawing Verication), showed that the most influential aspects of human resources to changes in Supreme Audit Board opinion is Behavior aspect (ethics).

- Conduct (Ethics) not honest in presenting the financial statements of the main factors causing changes Supreme Audit Board opinion of Qualified to Disclaimer Financial Statements of Local Government. 
To obtain the "Improved" Opinion towards Unqualified opinion or Qualified Opinion Local Government needs to do Strategy;

- $\quad$ Each Chief Local work unit make Fact integrity and commitment to achieve unqualified.

- Forming a team Supervise and Monitoring Action Plan against the Internal Control System Implementation and follow-up Resolution Auditors findings.

- Give priority to competence development program human resources administration and accounting fields Regional Finance.

\section{Reference}

Arfianti, D. \& Kawedar, W. (2011). Analysis of Factors Affecting The Value of The Government Financial Reporting Information, Faculty of Economics Diponegoro University, Semarang, 2011.

Audit Board of Indonesia. (2014). Summary of Results of Audit Semester II, Jakarta, 2014.

Herawati, T. (2014). Effect Of Internal Control System on The Quality Of Financial Statement, STAR Study. Journal of Accounting Research, 11(1).

Indonesian Government Regulation Number 101. (2000).

Concerning Education and Job Training for Civil Servants, Jakarta, 2000.

Indonesian Government Regulation Number 60. (2008). Concerning Government Internal Control System, 2008.

Indonesian Government Regulations, Number. 71. (2010). About the change of Government Regulation Number. 24 Year 2005 About the Government Accounting Standards 2010.

Law Number 17. (2003). About the State Finance, Jakarta, 2003.

Law Number 1. (2004). On the State Treasury, Jakarta, 2004.

Law Number 15. (2004). About the examination, Management and Responsibility of State Finance, Jakarta, 2004.

Moeller, R. R. (2007). COSO Enterprise, Risk Management; Understanding the New Integrated ERM Framework, New Jesrey, John Wiley \& Sons Inc, 2007.

Moleong L. J. (2002). Qualitative Research Methods, PT. Remaja Rosdakarya, Bandung, 2002.

Nasution. (1988). Naturalistic Qualitative Methods, Tarsito, Bandung, 1988.

Sugiyono. (2013). Understanding Qualitative Research Alfabeta, Bandung, 2013.

Susilawati, J. \& Riana, S. D. (2014). The Government Accounting Standards (SAP) and the Internal Control System (SPI) as Antecedents Quality Financial Statements. Star-Study Journal of Accounting Research, $11(1)$.

Suwanda, D. (2013). Strategy Getting Unqualified Opinion, PPM, Jakarta, 2013. 